\title{
Two Faces of Regulatory T Cells: From Immune Defense to Tumoral Progression
}

\author{
S. S. D. E. Medeiros ${ }^{1}$, L. G. De Souza ${ }^{1}$, W. M. Souza ${ }^{1}$, M. G. C. Mayeiro ${ }^{1}$ \\ and G. R. Degasperi ${ }^{1 *}$ \\ ${ }^{1}$ Ponthifical Catholic University of Campinas (PUC-Campinas), Center for Health Science, Brazil.
}

Authors' contributions

This work was carried out in collaboration among all authors. All authors read and approved the final manuscript.

Article Information

DOI: $10.9734 / A R R B / 2020 / v 35 i 1230317$

Editor(s):

(1) Dr. Viduranga Y. Waisundara, Australian College of Business \& Technology, Sri Lanka.

(1) Kaustav Chakraborty, S.B.S. Government College Hili (affiliated to University of Gour Banga), India.

(2) Carmine Finelli, Italy. Complete Peer review History: http://www.sdiarticle4.com/review-history/63638

Mini-review Article

Received 10 October 2020

Accepted 15 December 2020

Published 29 December 2020

\section{ABSTRACT}

$\mathrm{T}$ cells are the most important cellular element of human immunity defending against virus, bacteria, non-self-tissue and tumor cells. Regulatory T cells (Tregs) are the major responsible for self-tolerance maintenance, especially those expressing forkhead box protein 3 (FOXP3) transcription factor. Tregs suppressive function is established through several mechanisms that are essential to immune system homeostasis, but also related to tumoral microenvironment. Recent studies have provided deeper understanding of Tregs role in cancer as well as promising therapeutic targets for improving prognosis in cancer patients. This review approaches Tregs subtypes, functions and its implication in tumor progression.

Keywords: T regulatory cells; FOXP3; Cancer.

\begin{tabular}{|c|c|c|c|}
\hline$A B E$ & IATIONS & & $\begin{array}{l}\text { Immune Checkpoint Inhibitor } \\
\text { Forkhead box P3 }\end{array}$ \\
\hline$D N$ & Double Negative & $\begin{array}{l}\text { FOXP3 } \\
\text { ETP }\end{array}$ & $\begin{array}{l}\text { : Forkhead box P3 } \\
\text { : Early Thymic Progenitor }\end{array}$ \\
\hline$P C$ & : Progenitor cells & $P C$ & Progenitor Cells \\
\hline$W T$ & : Wild type & $T C R$ & $T$ cell receptor \\
\hline
\end{tabular}

*Corresponding author: E-mail: giovannadegasperi@puc-campinas.edu.br; grdegasperi@yahoo.com.br; 

NK cells : Natural Killer cell
TME : Tumoral Microenvironment
MHC : Major Histocompatibility Complex
$P D-1 \quad$ : Programmed cell death-1
Teff : Effector $T$ cells
TGF- $\beta$ : Transforming Growth Factor Beta
$m A b$ : monoclonal antibodies

\section{INTRODUCTION}

T cells are the most important cellular element of human immunity and play a fundamental role in defending against virus, bacteria, non-self tissue and tumor cells. From the bone marrow, $T$ cells migrate to the thymus, undergo several differentiations, are selected and become mature T cells [1].

Tregs, specially expressing FOXP3, are the major responsible for self-tolerance maintenance and various subsets, characterized by different cytokines, receptors and function, are elucidated. Treg-mediated suppression mechanismsinclude generation of inhibitory cytokines, such as IL-10 and TGF- $\beta$, death of effector cells by cytokine deprivation, and inhibition of dendritic cell (DC) functions [2,3].

Literature data demonstrated that high infiltration of Tregs in the tumoral microenvironment prevents effective anti-tumor immunity and leads to tumoral progression; therefore it is considered a sign of poor prognosis in several types of cancer [3]. In this scenario, monoclonal antibodies and low leptin plasma levels are promising therapeutic strategies.

This review will focus on Treg subsets and functions, particularly highlighting their participation in tumors environment.

\section{T CELLS DEVELOPMENT}

Hematopoietic stem cells in the bone marrow are responsible for providing the progenitor cells (PC) of the future T cells. Classically, multipotent PC differentiate into two strains: the common myeloid and lymphoid progenitors [4,5]; this leads to $\mathrm{T}$ cells, B cells and natural killers (NK) cells.

The thymus is constituted by two identical lobes, each one divided into a central medulla and a peripheral cortex, where the maturation and differentiation of $P C$ into $T$ cells occurs [6]. Thymus layers are divided into: cortex, corticomedullary junction, medulla, and subcapsular zone [7]. Cortical epithelial thymic cells are the major constituent of the subcapsular zone, but are also present in the cortex, with fibroblasts and macrophages. In turn, corticomedullary junction comprises endothelial cells that facilitate the flow of thymocytes through the circulatory current.

Following the differentiation process, cells that reach the cortical-medullary zone are named early thymic progenitor (ETP). Since they do not express CD4 or CD8 markers, they are known as double negative (DN) cells. This stage includes four phases as explained below [6].

Cells in DN1 phase remain in the corticalmedullary zone for approximately 10 days and are characterized by a large expression of CD117 marker and the presence of Notch1 receptor. Recent studies show that Notch1 signaling inhibits other ETP potentials from becoming the myeloid lineage or B cells.

As DN1 cells enter the cortical zone, they undergo stimulation and differentiate into DN2 $[8,9]$. Here, the genetic rearrangement process is initiated at the T cell receptor (TCR) $\gamma, \delta$, and $\beta$ gene loci [9]. The expression of CD117 reduces progressively as the subgroup $\mathrm{DN} 2 \mathrm{a}$ is transformed into DN2b [10]. Both still have the potential to become NK cells, but only DN2a can originate a DC.The transition DN2b-DN3 is a critical point for the definitive $T$ lineage through specification into $\alpha \beta$ or $\gamma \delta T$ cells. These DN3 cells continuously react their DNA at the $\beta, y$, and $\delta$ loci to increasingly express TCRs [10].

Finally, the cells migrate to the medullary zone and become DN4 cells. Nineteen days after the arrival of the progenitor cell in the thymus, as future $\mathrm{T}$ cells circulate through the cortex again, the pre-TCR signals and the cells express both CD4 and CD8 markers, establishing the double positive stage [6].

The next steps are the positive and negative selection. The first tests the strength and specificity of the connection between $\alpha \beta$ TCR and MHC (major histocompatibility complex) of cells present in the thymic cortex such as DC, cortical epithelial thymic cells and fibroblasts. If there is insufficient avidity of the receptor by the $\mathrm{MHC}$, there is apoptosis of the cell. The survivors start to express TCRs restricted to the individual's own MHC, and commit to the CD4 or CD8 lineage, depending on the prevalence of affinity for MHC class II or I respectively [1]. The 
second selection occurs in the thymus medullary zone and eliminates, by apoptosis, cells whose TCR has a high affinity for its own antigen in order to avoid future autoimmune reactions.

\section{FOXP3 TRANSCRIPTION FACTOR}

Tregs share a striking ability to promote a reasonable operation of immune system disposing of a wide repertoire of particularities such as the high expression of CD25, CTLA-4 (cytotoxic T-lymphocyte associated protein 4), $\alpha \beta$ TCR and FOXP3. Chatila et al. [11] related FOXP3 mutations to a severe immunodeficiency, polyendocrinopathy and enteropathy $\mathrm{X}$-linked syndrome (IPEX), a fatal immune disorder. Right after, FOXP3 was defined as fundamental for immune homeostasis [12] and modulation of CD4+ $T$ cells due to its ability to repress other transcription factors and cytokines related to $T$ cells activation [13]. Indeed, recent literature supports it as a 'master transcription factor' and a key to confer Tregs identity.

First, it is indispensable to understand how to guarantee an ideal FOXP3 expression. Attias et al. [14] demonstrated that FOXP3 expression rises once activated its promoter. In Tregs,

Table 1. Suppressive mechanisms of regulatory $T$ cells

\begin{tabular}{|c|c|c|c|}
\hline Types of & Specific mechanisms & studied & References \\
\hline \multirow{3}{*}{ Contact-dependent } & $\begin{array}{l}\text { Downregulation of } \\
\text { costimulatory } \\
\text { molecules on APCs }\end{array}$ & $\begin{array}{l}\text { CTLA-4 causes } \\
\text { extrinsic depletion of } \\
\text { APC ligands CD80/86 }\end{array}$ & $\begin{array}{l}\text { Qureshi et al., } 2011 \text { [67] } \\
\text { Onishi et al. } 2008 \text { [68] }\end{array}$ \\
\hline & $\begin{array}{l}\text { Starvation of T cells } \\
\text { by induced } \\
\text { catabolism of } \\
\text { essential amino acid } \\
\text { tryptophan }\end{array}$ & $\begin{array}{l}\text { CTLA-4 stimulate IDO } \\
\text { expression in human } \\
\text { and murine DC subsets } \\
\text { to induce catabolism }\end{array}$ & Yan et al., 2010 [69] \\
\hline & $\begin{array}{l}\text { Suppression of DC } \\
\text { maturation }\end{array}$ & $\begin{array}{l}\text { LAG-3 on Treg cells } \\
\text { interacts with MHC-II of } \\
\text { immature DC }\end{array}$ & $\begin{array}{l}\text { Liang et al., } 2008[70] \\
\text { Rueda et al., } 2016[71] \\
\text { Akkaya et al., } 2019[72] \\
\text { Takodoro et al.,2006 [73] } \\
\text { Mavin et al., } 2017[74]\end{array}$ \\
\hline $\begin{array}{l}\text { Metabolic } \\
\text { perturbation of } \\
\text { target cells }\end{array}$ & $\begin{array}{l}\text { Cytolysis of target } \\
\text { cells }\end{array}$ & $\begin{array}{l}\text { Treg cells express } \\
\text { granzymes } A \text { and } B \text { to } \\
\text { induce cytolysis }\end{array}$ & $\begin{array}{l}\text { Gondek et al., } 2005 \text { [75]. } \\
\text { Grossman et al., } 2004 \text { [76]. }\end{array}$ \\
\hline \multirow{3}{*}{$\begin{array}{l}\text { Immunomodulatory } \\
\text { cytokines }\end{array}$} & \multirow[b]{2}{*}{$\begin{array}{l}\text { IL-10 modulates } \\
\text { specialized functions } \\
\text { in mucosal interfaces }\end{array}$} & $\begin{array}{l}\text { IL-10 limits } \\
\text { immunological hyper } \\
\text { reactivity at colon, skin } \\
\text { and lungs }\end{array}$ & $\begin{array}{l}\text { Rubtsov et al., } 2008 \text { [77] } \\
\text { Chaudhry et al., } 2011 \text { [78]. }\end{array}$ \\
\hline & & $\begin{array}{l}\text { IL-10 regulates Th17 } \\
\text { immune response } \\
\text { IL10 contributes to } \\
\text { Foxp3 functions by } \\
\text { modulating the } \\
\text { expression of Foxo } 1 \\
\text { and STAT3 }\end{array}$ & Hsu et al., 2015 [79]. \\
\hline & $\begin{array}{l}\text { TFG- } \beta \text { regulates } \\
\text { allergic and } \\
\text { autoimmune } \\
\text { processes in mucosal } \\
\text { interfaces }\end{array}$ & $\begin{array}{l}\text { TGF- } \beta \text { reduces } \mathrm{TH} 17 \\
\text { cell responses in } \\
\text { gastrointestinal tract }\end{array}$ & Konkel et al., 2017 [80]. \\
\hline
\end{tabular}


the high expression of CD25 confers higher sensitivity to IL-2 signaling than T conventional (Tconv) cells. Through this, enough IL-2 is available to activate the signal transducer and activator of transcription (STAT)-5, which binds to various FOXP3 promoter sites. Likewise, transforming growth factor beta (TGF- $\beta$ ) promotes FOXP3 expression when conversing naïve Tconv to induced Treg cells as detailed ahead (subsection 4). Thus, the presence of cytokines signaling is necessary to maintain enough levels of FOXP3.

Considering this, FOXP3 may highlight Tregs' mechanisms of suppression and its associated pathways, which are elucidated in Table 1 . The main mechanisms involve contact-dependent methods; metabolic perturbation of target cells; and use of immunomodulatory cytokines [15], all of them required for clarifying key points in peripheral tolerance maintenance and how disorders can result in numerous diseases. By acknowledging each one in further detail, greater are the possibilities of discovering new effective treatments and therapies for such conditions.

\section{SUBSETS OF REGULATORY T CELLS}

Tregs can be differentiated into two ontogenic categories. The first subset involves thymus derived Treg cells, also known as natural Tregs (nTreg). These $\mathrm{CD} 4^{+} \mathrm{CD} 25^{+}$Tregs originate from immature precursors from thymus and are specifically responsible for tolerance to selfantigens due to their considerable TCR avidity to them. Its various immunosuppression abilities include inhibitory cytokines production [16], cellto-cell contact [17], T cell induced apoptosis [18] and blocking of T cell activation [19].

The other branch encompasses induced Tregs (iTreg) [20] which emerge from naive $\mathrm{CD} 4^{+} \mathrm{CD} 25^{-}$ Tconv in peripheral lymphoid tissues and assume non-self-antigen tolerance including commensal and environmental antigens. iTregs differentiation mainly occurs in mucosal interfaces where specialized antigen-presenting cells (APCs) produces inducing cytokines [21]; for instance TGF- $\beta$ and IL-2 production by dendritic cells in gastrointestinal tract in the presence of retinoic acid and, likewise, by alveolar macrophages in the lungs [22]. These same factors associated with TCR activation of naive $T$ cells can originate iTregs in vitro [23].

Therefore, nTregs and iTregs play distinct roles since they present different responses and, consequently, distinguished effectiveness towards each condition of metabolic stress or autoimmune disease. These complementary approaches contribute to a non-overlapping teamwork, to lesser susceptibility to organism general destabilization and to a more complete immunological defense for maintaining adequate peripheral tolerance.

Both $n$ Tregs and iTregs present similar levels of FOXP3 in normal conditions. However, inflammatory scenarios may cause destabilization and even loss of FOXP3 expression in Treg cells [24]. Besides, it is important to emphasize the existence of FOXP3 ${ }^{-}$ Tregs as assistants to those $\mathrm{FOXP}^{+}$in the architectural process of balancing the immune system through suppressive functions. Here Tr1 and Th3 Treg cells are highlighted.

Th3 cell differs from classical Tregs because of the absence of FOXP3 and CD25; and from other T helper cells - Th1,Th2 - for its ability to secret TGF- $\beta$ and so provide this growth factor to be used by $\mathrm{FOXP3}{ }^{+}$Tregs in peripheral tolerance [25]. Also, Th3 expresses a latency-associated peptide to bind to TGF- $\beta$ and form inactive complexes. Thus, this $\mathrm{CD} 4^{+} \mathrm{CD} 25^{-}$FOXP3-LAP ${ }^{+}$ cell plays a supporting role for Tregs in softening autoimmune and inflammatory conditions.

Tr1 cells do not express FOXP3 or CD25 either, yet they present a unique attribute including not only TGF- $\beta$ but also IFN- $\gamma$, IL-5 and IL-10 production [26]. This last cytokine might be essential for Tr1 differentiation, although its specific transcription factor is yet unknown. In fact, studies showed that CD4+ T cells are induced to suppressive IL-10-producing Tr1 cells by nasal antigen [27] andby TGF- $\beta$ allied to IL-27 produced by dendritic cells modified by Tregs [28]. CD49b, LAG3 and CD226 are some of the surface markers listed recently for Tr1 cells [29].

Beyond the classical immune portrait of Tregs, it is relevant to underline its functional plasticity in expressing diverse non-immune functions in response to tissue environment adaptation [30]. Unfortunately, these competences can result in pathogenic scenarios, where Tregs reprogramming ends to perpetuate pathological chronic conditions such as inflammatory, allergic and autoimmune diseases [15].

In the inflammatory condition of obesity, Tregs resident in visceral adipose tissue, also known as 'Fat Tregs', are involved in controlling metabolic parameters [31]. 


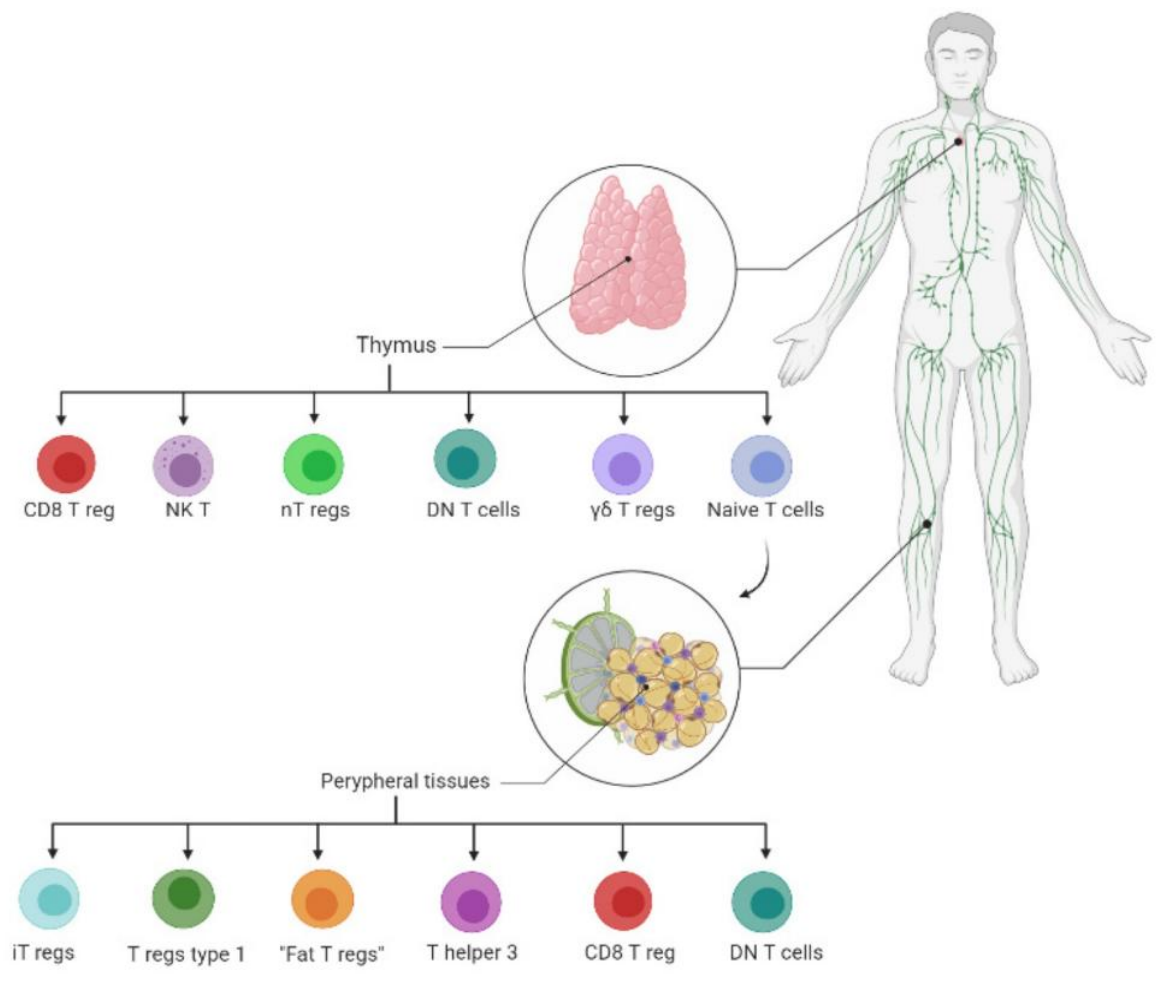

Fig. 1. Tregs Subtypes differentiation from the thymus

The regulatory $T$ cells can be divided into two ontogenetic categories: natural regulatory $T$ cells and induced regulatory $T$ cells. The first subset of cells is produced in the Thymus, and emerge from immature precursors.

The other is produced in peripheral tissues and emerges from naive $T$ cells following specific antigenic stimulation.

CD8 T reg: CD8+ regulatory T cells; NK T: Natural killer T cells; $n$ Tregs: natural Tregs; DN T cells: Double negative $T$ cells; $\gamma \delta T$ regs: $\gamma \delta$ regulatory $T$ cells; iTregs: induced Tregs

These cells are distinct from lymphoid organ Treg cells. They have specific mechanisms to regulate immune response and metabolic states in normal or pathologic conditions [32]. It was demonstrated that Treg cells from visceral adipose tissue are reduced in different experimental models of obesity, such as ob/ob leptin-deficient mice and high fat diet-induced obese mice. However, high percentage and absolute number of circulating Treg cells were observed in leptin-deficient ob/obmice [33]. In this experimentalmodel, adoptive transfer of Treg cells from WT mice showed in vivo expansion of Treg cells [34]. In another study, it was highlighted the effect of leptin on Treg cells proliferation. It was suggested that in lean fat tissue that is related to little leptin, high proliferation of Treg cells was observed. In contrast, few Treg cells was observed in obese fat [35]. Likewise, fasting-induced hypoleptinemia in lupus-prone mice caused the expansion of functional Tregs that was reversed by leptin treatment [36]. These findings reflect the inhibitory properties of leptin in Treg cells and their consequent pro-inflammatory and autoimmune effects. Thus, hypoleptinemia is a beneficial intervention for those chronic conditions.

\section{TREGS ROLE IN TUMOR PROGRESS- ION}

From pioneer to recent studies, literature reveals Tregs involvement in tumor immunity $[37,38]$. Yet in the 90's, it was reported that depletion of $\mathrm{CD} 4^{+} \mathrm{CD} 25^{+}$Tregs in tumor-bearing mice by treatment with anti-CD25 antibody is associated with tumor rejection. Similar results were found with Treg deficient mice that were given splenocytes treated with anti-CD25 [37]. Afterwards, it became well established that high levels of Tregs in tumoral microenvironment (TME) from different types of cancer in humans corresponds to poor prognosis [39]. More 
recently, parallel results are observed with decreased ratios of $\mathrm{CD}^{+} \mathrm{T}$ cells to Tregs in breast, ovarian and gastrointestinal tumors $[38,39]$. In contrast, higher infiltration of Tregs is correlated with better prognosis in some cancers, such as colorrectal, head and neck and bladder cancer [40]. Naturally, Tregs infiltration may be beneficial in some contexts as for its ability to regulate inflammatory, allergic, and autoimmune conditions, [41] including to suppress inflammatory response to gut microbes in colorectal cancer [42]. In general, however, higher infiltration of Tregs remains associated with poor prognosis in cancer and new therapies focus on depleting or inhibiting Tregs suppressive mechanisms [42].

In fact, in TME, cancer cells adapt mechanisms to escape immune surveillance through promotion of immunosuppressive conditions related to Tregs, tumor associated macrophages and immunosuppressive molecules and cytokines [42]. Beyond that, various chemokines produced by tumor or host cells are involved in Tregs recruitments to TME by chemo-attraction and combination of chemokine-chemokine receptors. Such combinations differ from each cancer but the most important are: CCL17/22CCR4, CCL5-CCR5, CCL28-CCR10 and CXCL9/10/11-CXCR3 [43]. For instance, CCR4 is bound by CCL22 in breast and ovarian cancer [44] while in colorrectal, oral squamous cancer and Hodgkin lymphoma, it is bound by undefined chemokines [44].

Still, Tregs present in TME, unlike Treg cells in non-lymphoid tissues, lymphoid tissues or blood, have a highly activated status with major expression ofsuppressive cell surface molecules such as CD25, PD-1,CTLA-4 and TIGIT [45]. TME has also many tumor-associated antigens from dying tumor cells, which are rather recognized by Tregs instead of effector $T$ (Teff) cells by high-affinity TCR, causing clonal expansion of Tregs in TME by neoantigens. Also, dendritic, cancer and stromal cells produce abundant growth factors and molecules facilitating expansion of Tregs through conversion of Tconvcells iniTregs: TGF- $\beta$, IL-10, indoleamine 2,3-dioxygenase (IDO), cyclooxygenase 2 (COX-2) and prostaglandin E2 (PGE2) [45].

Under these conditions, Treg cells suppress activation, proliferation and function of immune effector cells and settle an immunosuppressive milieu. First, there is expression of co-inhibitory molecules such as PD-1, LAG-3, TIM-3, TIGIT and CTLA-4, the latter being a key negative regulator of $T$ cell activation, expressed by Tregs $[46,47]$. Furthermore, as Tregs produces IL-10, IL-35 and TGF- $\beta$ inhibitory cytokines, there is great consumption of IL-2, due to Tregs high affinity to IL-2 receptor, resulting in lesser IL-2 available for proliferation and activation of Teffs.

In summary, Tregs play inhibitory effects by three main mechanisms in TME: generation of inhibitory cytokines and proteins; death of effector cells by cytokine deprivation; and inhibition of dendritic cell (DC) functions [2,3]. Tregs produce immunomodulatory cytokines such as IL-10, TGF- $\beta$ and IL-35, inhibiting the immune function against cancer [46]. They also secrete granzymes and perforin, leading to apoptosis of $\mathrm{NK}$ and $\mathrm{CD} 8+\mathrm{T}$ cells and reducing tumor clearance. Still, Tregs produces extracellular enzymes CD39 and CD73, increasing adenosine in the TME, which is a known inhibitory molecule that binds to A2A receptors on the surface of Teffs [48]. The death of effector cells is due to Tregs competition and consumption of large amounts of IL-2, leading to IL-2 withdrawal in TME, like so, inhibiting Teffs growth. Additionally, the accumulation of Tregs in the TME impairs the functionality of the DCs, since CTLA-4 expressed by Tregs binds with costimulatory molecules CD80 and CD86 on DCs and downregulates its signaling by transendocytosis [47]. Likewise, LAG3 expressing Tregs suppress MHC II expression on DCs. The last two methods can further impair $\mathrm{T}$ cell incapacity by IDO Finally, Tregs suppressive mechanisms are perpetuated in TME through: chemotaxis of Tregs to tumor infiltrates in lymph nodes (specially for CCR4 and CCR8 receptors); the conversion of Teffs into Tregs by stimulating TCR and TGFb; clonal expansion of Tregs by neoantigens; and through its interaction to myeloid derived suppressor cells (MDSCs), which forms positive feedback loops that enhances each other population expansion: MDSCs promotes induction of Tregs by producing IL-10, TGF- $\beta$, CD73 and IDO, and Tregs promotes induction of MDSCs by producing IL-35 and TGF- $\beta$ (Fig. 3).

As discussed in subsection 4, high leptin plasma levels that can be found in conditions of obesity, seem to decrease Treg numbers and so have been considered for prevention and treatment of certain tumor types. Therefore, leptin could 


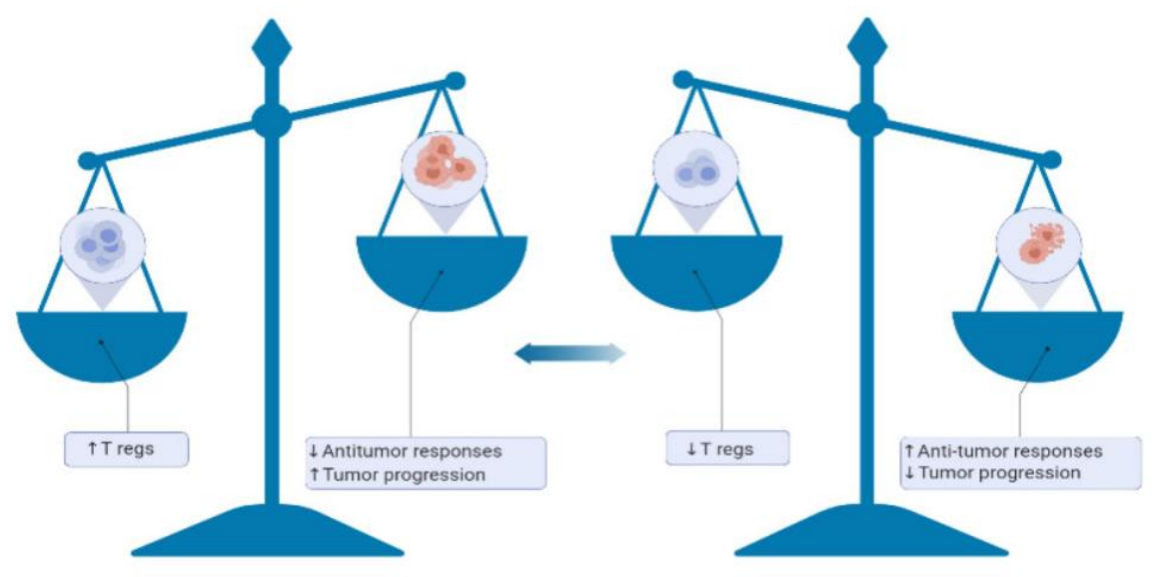

Fig. 2. Balance between regulatory $\mathrm{T}$ cells numbers and anti-tumor responses/tumor progression

The number of regulatory $T$ cells are associated with tumor progression or suppression. Tregs: regulatory $T$ cells

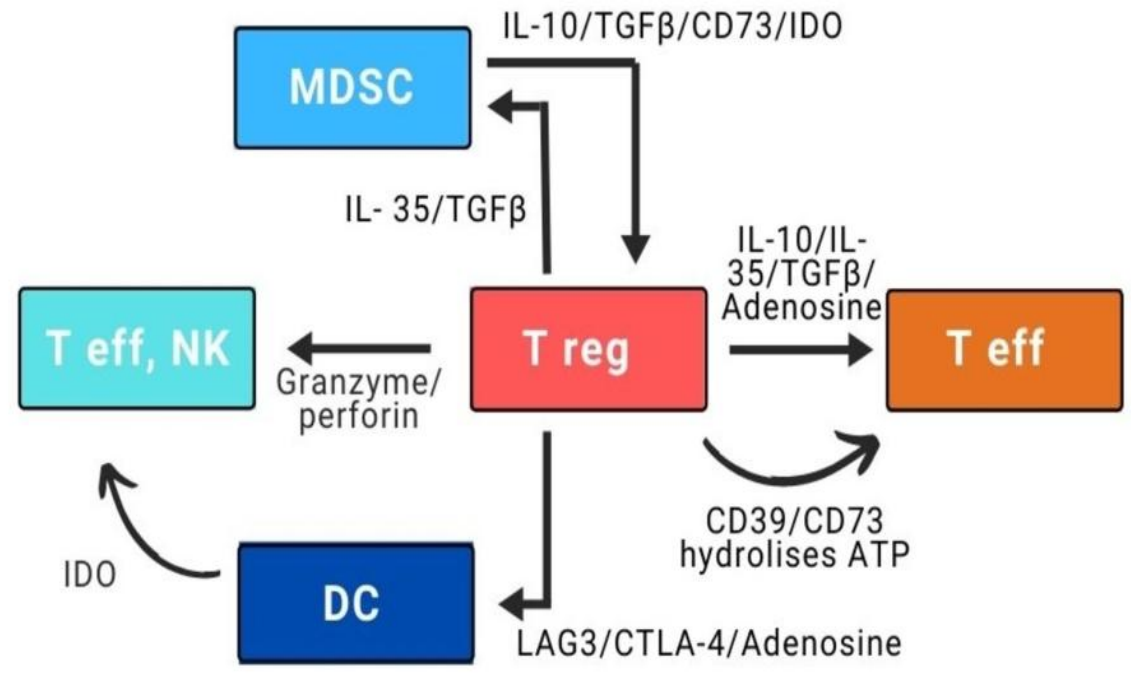

Fig 3. Regulatory T cells immunosuppressive roles in tumoral microenvironment

There are three main mechanism: (1) generation of inhibitory cytokines and proteins, including (1a) secretion of IL-10, IL-35 and TGF- $\beta$, (1b) granzymes and perforin and (1c) extracellular enzymes CD39 and CD73; (2) death of effector cells by IL-2 cytokine deprivation; (3) inhibition of DC functions through (3a) downregulation by CTLA-4 and (3b) LAG 3. Besides, it is shown the perpetuation of such mechanisms in tumoral microenvironment due to chemotaxis of Tregs, the conversion of Teffs into Tregs, clonal expansion of Tregs by neoantigens, and Tregs stimulating interaction to MDSC.Treg: regulatory T cells. IL: interleukin. DC: dendritic cells. TGF- $\beta$ : transforming growth factor beta. CTLA-4: cytotoxic T-lymphocyte associated protein 4. LAG 3: Lymphocyte-associated gene 3 Teff: effector T cells. MDSC: myeloid derived suppressor cells.IDO-indoleamine 2,3-dioxygenase

contribute to lesser infiltration of Tregs in the tumor environment and to a better prognosis for cancer patients. In addition, leptin can also be involved in in the response of immunotherapy in obese patients $[49,50]$. Obese patients with metastatic melanoma showed a better response to immune checkpoint inhibitors anti-PD1/PD-L1 [51]. It was demonstrated, however, that low levels of leptin contributes against tumor development in some contexts. Fasting with low levels of leptin is a possible strategy for both $B$ and $\mathrm{T}$ cell acute lymphoblastic leukemia as it 
inhibits leukemic initiation and progression, but in this condition, Treg cells are not involved in the anti-tumoral mechanisms [52].

\section{TREGS AS TARGETS OF CANCER IMMUNOTHERAPY}

Since Treg cells narrow effective immune surveillance and responses, they are the main character in TME allowing cancer growth. For this reason, many techniques have been developed aiming to reduce Tregs activity, mostly in TME, in order to avoid autoimmune diseases, including: depletion of Tregs, disruption of Tregs to the TME, suppression of Treg function and inhibition of iTreg generation [3,53]. Importantly, immune checkpoint molecules - co-inhibitory ligands that downregulate activation of $T$ cells - are often upregulated in intratumoral lymphocytes [54].

Wherefore, using immune checkpoint inhibitors (ICl), consisting of blocking antibodies for immune checkpoint molecules, is a promising therapeutic strategy, since $\mathrm{ICl}$ approaches have shown relevant success in many types of cancer, yet limited to $10-20 \%$ of the patients $[54,55]$. ICI targeting CTLA-4 was the first targeted immune checkpoint molecule, with two fully humanized anti-CTLA-4 monoclonal antibodies (mAb) of IgG1 and IgG2 developed: ipilimumab and tremelimumab, respectively. The former has been approved by FDA for the treatment of nonsmall cell lung cancer, melanoma, bladder cancer and renal carcinoma [56]. The last, has been studied in clinical trials for melanoma, colon cancer, and mesothelioma $[57,58]$. Thus, the increased antitumor effects by anti-CTLA-4 mAb are mostly due to the suppression and elimination of Treg in the TME [59]. Programmed cell death-1 (PD-1) protein and its ligand (PD-L1) have been front-line $\mathrm{ICl}$ targets for melanoma and lung cancer immunotherapies, avoiding the suppression of CD8+ $T$ cells and allowing them to effectively pursue tumor cells $[60,61]$.

Other possible targets for Tregs depletion and manipulation has been tested in current clinical trials with promising results: OX40 and GITR molecules [62,63]. Both are co-stimulatory receptors expressed by Tregs and are members of the TNF receptor superfamily, reducing Tregs suppressive function. OX40 promotes survival and effector function of Teffs, and, in animal models, an anti-OX40 agonistic antibody enhance anti-tumor responses in melanoma, glioma, sarcoma, colon, breast, renal and prostate cancer [62]. Likewise, activation of GITR signaling with its ligands or agonistic antibody inhibits FOXP ${ }^{+}$Tregs activity and turns Teffs sheltered to their mediated suppression [63]. Additionally, in mouse models, anti-GITR antibody prompted strong anti-tumor responses in fibrosarcoma, colorectal carcinoma and melanoma models while decreased Treg levels.

A recent study demonstrated effective tumor regression combining strategies to block TGF- $\beta$ signalling in Th cells and inhibit vascular endothelial growth factor (VEGF) in TME. Indeed, previous studies have evidentiated the suppression of anti-tumour immunity by TGF- $\beta 1$ produced by activated CD4+ T cells, rather than by Tregs or cancer cells [64-66]. Thus, Li et al. 2020 designed the CD4 TGF- $\beta$ Trap (4-T-Trap), a TGF- $\beta$-neutralizing TGFBR2 extracellular domain linked to ibalizumab. The association to VEGF inhibitors amplifies its antitumor effect since it is necessary to neutralize the increase in proangiogenic factors resulting from the tumour tissue hypoxia induced by 4T-Trap in order to achieve an effective cancer defence response [64].

Wherefore, antibodies that are able to restrict suppressive functions of Tregs and other molecules in TME through inhibition of coinhibitory or stimulation of co-stimulatory molecules, potentiate effector immunity elements, thus acting as promising therapeutic targets. Many are the immunotherapeutic possibilities for fighting cancer, making it a necessary and growing field of modern research.

\section{CONCLUSION}

Tregs are essential for an adequate immunological defense towards metabolic stress and autoimmune conditions and a key to peripheral tolerance maintenance. However, they are a signal of poor prognosis in the tumoral microenvironment as inhibiting effector $\mathrm{T}$ cells responses to tumor progression. Monoclonal antibodies that regulate the inhibitory activity of Tregs are promising therapeutic targets for cancer treatment. Therefore, more research is needed in order to boost the comprehension of such conditions and the discovery of new biomarkers, essentials to amplify immunotherapy spectrum and predict immune responses.

\section{COMPETING INTERESTS}

Authors have declared that no competing interests exist. 


\section{REFERENCES}

1. Koche U, Radtke F. Mechanisms of T Cell development and transformation. Annu. Rev. Cell. Dev. Biol. 2011;27:539-62.

Accessed 21 November 2019. Available: https://pubmed.ncbi.nlm.nih.gov/21740230/

2. Tanaka A, Sakaguchi S. Targeting Treg cells in cancer immunotherapy. Eur J Immunol. 2019;49(8):1140-1146.

Accessed 11 December 2020

Available:https://pubmed.ncbi.nlm.nih.gov/ 31257581/

3. Kim JH, Kim BS, Lee SK. Regulatory T cells in tumor microenvironment and approach for anticancer immunotherapy. Immune Netw. 2020;20(1):e4.

Accessed 02 April 2020.

Available:https://www.ncbi.nlm.nih.gov/pm c/articles/PMC7049587/

4. Akashi K, Traver D, Miyamoto $\mathrm{T}$, Weissman IL. A clonogenic common myeloid progenitor that gives rise to all myeloid lineages. Nature. 2000;404:193-7. Accessed 15 December 2019

Available:https://pubmed.ncbi.nlm.nih.gov/ 10724173/

5. Petrie HT, Zúñiga-Pflücker JC. Zoned out: Functional mapping of stromal signaling microenvironments in the thymus. Annu. Rev. Immunol. 2007;25:649-79. Accessed 27 February 2020. Available: https://pubmed.ncbi.nlm.nih.gov/17291187/

6. Zdrojewicz Z, Pachura E, Pachura P. The thymus: A forgotten, but very important organ Adv. Clin. Exp. Med. 2016;25:369_ 75.

Accessed 02 April 2020

Available:https://pubmed.ncbi.nlm.nih.gov/ 27627572/

7. Allman D, Sambandam A, Kim S, Miller JP, Pagan A, Well D, et al.. Thymopoiesis independent of common lymphoid progenitors. Nat. Immunol. 2003;4:168-74. Accessed 07 December 2019

Available:https://pubmed.ncbi.nlm.nih.gov/ 12514733/

8. Takahama Y. Journey through the thymus: Stromal guides for T-cell development and selection. Nat. Rev. Immunol. 2006;6:12735.

Accessed 13 November 2019

Available:https://pubmed.ncbi.nlm.nih.gov/ 16491137.

9. Livák $F$, Tourigny $M$, Schatz DG, Petrie HT. Characterization of TCR gene rearrangements during adult murine $T$ cell development. J. Immunol. 1999;162:2575-

80.

Accessed 06 December 2019

Available:https://pubmed.ncbi.nlm.nih.gov/ 10072498.

10. Burtrum DB, Kim S, Dudley EC, Hayday AC, Petrie HT. TCR gene recombination and alpha beta-gamma delta lineage divergence: productive TCR-beta rearrangement is neither exclusive nor preclusive of gamma delta cell development. J. Immunol. 1996;157:42936.

Accessed 08 April 2020

Available.https://pubmed.ncbi.nlm.nih.gov/ 8906802/.

11. Chatila TA, Blaeser $\mathrm{F}$, Ho N, Lederman HM, Voulgaropoulos C, Helms C, et al. JM2, encoding a fork head-related protein, is mutated in X-linked autoimmunityallergic disregulation syndrome. J. Clin. Invest. 2000;106(12):R75-R81.

Accessed 18 November 2019

Available:https://www.ncbi.nlm.nih.gov/pm c/articles/PMC387260/.

12. Brunkow ME, Jeffery EW, Hjerrild KA, Paeper B, Clark LB, Yasayko SA, et al. Disruption of a new forkhead/winged-helix protein, scurfin, results in the fatal lymphoproliferative disorder of the scurfy mouse. Nat. Genet. 2001;27:68-73.

Accessed 09 November 2019

Available:https://www.nature.com/articles/n g0101_68/.

13. Schubert LA, Jeffery E, Zhang Y, Ramsdell F, Ziegler SF. Scurfin (FOXP3) acts as a repressor of transcription and regulates $T$ Cell activation. J. Biol. Chem. 2001;276(40):37672-9.

Accessed 09 December 2019

Available:https://pubmed.ncbi.nlm.nih.gov/ 11483607.

14. Attias $\mathrm{M}, \mathrm{Al}$-Aubodah $\mathrm{T}$, Piccirillo $\mathrm{CA}$. Mechanisms of human FoxP3+ Treg cell development and function in health and disease. Clin. Exp. Immunol. 2019;197(1):36-51.

Accessed 11 February 2020

Available:https://pubmed.ncbi.nlm.nih.gov/ 30864147.

15. Georgiev P, Charbonnier LM, Chatila TA. Regulatory $T$ Cells: The many faces of Foxp3. J. Clin. Immunol. 2019;39(7):62340.

Accessed 13 March 2020.

Available:https://pubmed.ncbi.nlm.nih.gov/ 31478130/ 
16. Collison LW, Workman CJ, Kuo TT, Boyd $\mathrm{K}$, Wang $\mathrm{Y}$, Vignali $\mathrm{KM}$, et al. The inhibitory cytokine IL-35 contributes to regulatory T-cell function, Nature. 2007; 450(7169):566-9.

Accessed 31 March 2020.

Available:https://pubmed.ncbi.nlm.nih.gov/ 18033300/

17. Nakamura K, Kitani A, Strober W. Cell contact-dependent immunosuppression by CD4+CD25+ regulatory $T$ cells is mediated by cell surface-bound transforming growth factor $\beta$. J. Exp. Med. 2001;194(5):629-44. Accessed 30 March 2020

Available:https://pubmed.ncbi.nlm.nih.gov/ 11535631/.

18. Deaglio S, Dwyer KM, Gao W, Friedman $D$, Usheva A, Erat A, et al. Adenosine generation catalyzed by CD39 and CD73 expressed on regulatory $T$ cells mediates immune suppression. J. Exp. Med. 2007;204(6):1257-65.

Accessed 11 April 2020

Available:https://pubmed.ncbi.nlm.nih.gov/ 17502665/

19. Liang B, Workman C, Lee J, Chew C, Dale BM, Colonna L, et al. Regulatory T Cells inhibit dendritic cells by lymphocyte activation Gene-3 engagement of MHC Class II. J. Immunol. 2008;180(9):5916-26. Accessed 29 February 2020

Available:https://pubmed.ncbi.nlm.nih.gov/ 18424711/

20. Abbas AK, Benoist C, Bluestone JA, Campbell DJ, Ghosh S, Hori S, et al. Regulatory T cells: Recommendations to simplify the nomenclature. Nat. Immunol. 2013;14(4):307-8.

Accessed 09 December 2019

Available:https://pubmed.ncbi.nlm.nih.gov/ 23507634/

21. Gondek DC, Lu LF, Quezada SA, Sakaguchi S, Noelle RJ. Cutting edge: contact-mediated suppression by CD4 + $\mathrm{CD} 25+$ regulatory cells involves a granzyme B-Dependent, perforinindependent mechanism. J. Immunol. 2005;174(4):1783-6.

Accessed 21 April 2020

Available:https://pubmed.ncbi.nlm.nih.gov/ 15699103/

22. Esterházy D, Loschko J, London M, Jove V, Oliveira TY, Mucida D. Classical dendritic cells are required for dietary antigen-mediated induction of peripheral $\mathrm{T}(\mathrm{reg})$ cells and tolerance. Nat. Immunol. 2016;17:545-55.
Accessed 03 January 2020

Available:https://pubmed.ncbi.nlm.nih.gov/ 27019226/

23. Davidson TS, DiPaolo RJ, Andersson J, Shevach EM. Cutting edge: IL-2 is essential for TGF- $\beta$-mediated induction of Foxp3 + T regulatory cells. J. Immunol. 2007;178:4022-6.

Accessed 15 January 2020.

Available:https://www.jimmunol.org/content /178/7/4022/

24. Komatsu N, Okamoto K, Sawa S, Nakashima T, Oh-Hora M, Kodama T, et al. Pathogenic conversion of Foxp3 $+\mathrm{T}$ cells into $\mathrm{TH} 17$ cells in autoimmune arthritis. Nat. Med. 2014;20:62-8. Accessed 17 January 2020. Available: https://pubmed.ncbi.nlm.nih.gov/24362934/

25. Weiner HL, da Cunha AP, Quintana F, Wu $\mathrm{H}$. Oral Tolerance. Immunol. Rev. 2011;241:241-59.

Accessed 21 January 2020

Available:https://www.ncbi.nlm.nih.gov/pm c/articles/PMC3296283/.

26. Bacchetta $R$, Sartirana $C$, Levings $M K$, Bordignon C, Narula S, Roncarolo MG. Growth and expansion of human $T$ regulatory type 1 cells are independent from TCR activation but require exogenous cytokines. Eur. J. Immunol. 2002;32:223745. Accessed 13 January 2020. Available: https://pubmed.ncbi.nlm.nih.gov/12209636.

27. Zeng $H$, Zhang $R$, Jin B, Chen L. Type 1 regulatory $T$ cells: $A$ new mechanism of peripheral immune tolerance. Cell. Mol. Immunol. 2015;12:566-571.

Accessed 18 January 2020.

Available:https://www.nature.com/articles/c mi201544/.

28. Awasthi A, Carrier Y, Peron JP, Bettelli E, Kamanaka M, Flavell RA, et al. A dominant function for interleukin 27 in generating interleukin 10-producing anti-inflammatory T cells. Nat Immunol. 2007;8(12):1380-9. Accessed 25 January 2020. Available: https://pubmed.ncbi.nlm.nih.gov/17994022/

29. Gagliani N, Magnani CF, Huber S, Gianolini ME, Pala M, Licona-Limon P, et al. Coexpression of CD49b and LAG-3 identifies human and mouse $T$ regulatory type 1 cells. Nat. Med. 2013;19:739-46.

Accessed 03 February 2020

Available:https://pubmed.ncbi.nlm.nih.gov/ 23624599/

30. Levine AG, Medoza A, Hemmers S, Moltedo B, Niec RE, Schizas $M$, et al. Stability and function of regulatory $T$ cells 
expressing the transcription factor T-bet. Nature. 2017;546:421-5.

Accessed 13 March 2020.

Available:https://pubmed.ncbi.nlm.nih.gov/ 28607488/

31. Deiuliis J, Shah Z, Shah N, Needleman B, Mikami D, Narula V, et al. Visceral adipose inflammation in obesity is associated with critical alterations in tregulatory cell numbers. PLoS One. 2011;6.

Accessed 13 March 2020.

Available:https://pubmed.ncbi.nlm.nih.gov/ 21298111/

32. Zeng $Q$, Sun X, Xiao L, Xie Z, Bettini M, Deng T. A unique population: Adiposeresident regulatory $\mathrm{T}$ Cells. Front Immunol. 2018;9:2075.

Accessed: 11 December 2020.

Available:https://www.ncbi.nlm.nih.gov/pm c/articles/PMC6172295/.

33. De Rosa V, Procaccini C, Calì G, Pirozzi G, Fontana S, Zappacosta S, et al. A key role of leptin in the control of regulatory $T$ cell proliferation. Immunity. 2007;26(2): 241-55.

Accessed 10 December 2020

Available:https://pubmed.ncbi.nlm.nih.gov/ 17307705/

34. Trenado A, Charlotte F, Fisson S, Yagello M, Klatzmann D, Salomon BL, et al. Recipient-type specific CD4+CD25+ regulatory $T$ cells favor immune reconstitution and control graft-versus-host disease while maintaining graft-versusleukemia. J Clin Invest. 2003;112(11): 1688-96.

Accessed 10 December 2020

Available:https://pubmed.ncbi.nlm.nih.gov/ 14660744/

35. Feuerer M, Herrero L, Cipolletta D, Naaz A, Wong J, Nayer A, et al. Lean, but not obese, fat is enriched for a unique population of regulatory $T$ cells that affect metabolic parameters. Nat Med 2009;15(8):930-9.

Accessed 11 December 2020

Available:https://www.nature.com/articles/n m.2002/.

36. Liu Y, Yu Y, Matarese G, La Cava A. Cutting edge: Fasting-induced hypoleptinemia expands functional regulatory $\mathrm{T}$ Cells in systemic lupus erythematosus. J. Immunol. 2012;18:2070-3.

Accessed 08 Abril 2020

Available:https://pubmed.ncbi.nlm.nih.gov/ 22291185/
37. Shimizu J, Yamazaki S, Sakaguchi S. Induction of tumor immunity by removing CD25+CD4+ T cells: a common basis between tumor immunity and autoimmunity. J. Immunol. 199;163:52118.

Accessed 11 December 2019

Available:https://pubmed.ncbi.nlm.nih.gov/ 10553041/

38. Ahmadzadeh M, Pasetto A, Jia L, Deniger DC, Stevanović S, Robbins PF, et al. Tumor-infiltrating human CD4+ regulatory $\mathrm{T}$ cells display a distinct TCR repertoire and exhibit tumor and neoantigen reactivity. Sci. Immuno. 2019;4.

Accessed: 03 February 2020.

Available:https://pubmed.ncbi.nlm.nih.gov/ 30635355/

39. Plitas G, Rudensky AY. Regulatory $T$ cell in cancer. Annu. Rev. Cancer Biol. 2020;4:459-77. Accessed 08 December 2020.

Available:https://www.annualreviews.org/d oi/abs/10.1146/annurev-cancerbio-030419033428/.

40. Fridman WH, Pagès F, Sauts-Fridman C, Galon J. The immune contexture in human tumours: Impact on clinical outcome. Nat. Rev. Cancer. 2012;12:298-306.

Accessed 20 December 2019.

Available:

https://pubmed.ncbi.nlm.nih.gov/22419253/

41. Saleh R, Elkord E. FoxP3+ T regulatory cells in cancer: prognostic biomarkers and therapeutic targets. Cancer Lett. 2020;490:174-85.

Accessed 09 December 2020.

Available:https://www.sciencedirect.com/sc ience/article/pii/S0304383520303785/.

42. Chaudhary B, Elkord E. Regulatory T cells in the tumor microenvironment and cancer progression: Role and therapeutic targeting. Vaccines (Basel). 2016;4(3):28. Accessed 12 January 2020.

Available:https://pubmed.ncbi.nlm.nih.gov/ 27509527/

43. Gobert M, Treilleux I, Bendriss-Vermare N, Bachelot T, Goddard-Leon S, Arfl V, et al. Regulatory $T$ cells recruited through CCL22/CCR4 are selectively activated in lymphoid infiltrates surrounding primary breast tumors and lead to an adverse clinical outcome. Cancer Res. 2009;68:2000-9.

Accessed 10 December 2020

Available:https://pubmed.ncbi.nlm.nih.gov/ 19244125/ 
44. Svensson $H$, Olofsson $V$, Lundin $S$, Yakkala C, Björck S, Börjesson $L$, et al. Accumulation of CCR4+ CTLA-4hi FOXP3+CD25hi regulatory $\mathrm{T}$ Cells in colon adenocarcinomas correlate to reduced activation of conventional $\mathrm{T}$ Cells. PLoS One. 2012;7.

Accessed 5 November 2019

Available:https://journals.plos.org/plosone/ article?id10.1371/journal.pone.0030695/.

45. Topalian SL, Drake CG, Pardoll DM. Immune checkpoint blockade: A common denominator approach to cancer therapy. Cancer Cell. 2015;27:450-61.

Accessed 10 January 2020.

Available:https://pubmed.ncbi.nlm.nih.gov/ 25858804/

46. Wei X, Zhang J, Gu Q, Huang M, Zhang W, Guo J, et al. Reciprocal expression of IL-35 and IL-10 defines two distinct effector treg subsets that are required for maintenance of immune tolerance. Cell Rep. 2017;21(7):1853-1869.

Available:https://pubmed.ncbi.nlm.nih.gov/ 29141218/

47. Kalia V, Penny LA, Yuzefpolskiy Y, Baumann FM, Sarkar S. Quiescence of memory CD8(+) T Cells Is mediated by regulatory $T$ Cells through Inhibitory receptor CTLA-4. Immunity. 2015;42(6): 1116-29.

Accessed 10 December 2020

Available:https://pubmed.ncbi.nlm.nih.gov/ 26084026/

48. Ohta A, Kini R, Ohta A, Subramanian M, Madasu M, Sitkovsky M. The development and immunosuppressive functions of CD4(+) CD25(+) FoxP3(+) regulatory $\mathrm{T}$ cells are under influence of the adenosineA2A adenosine receptor pathway. Front Immunol. 2012;3:190.

Accessed 10 December 2020.

Available:.https://pubmed.ncbi.nlm.nih.gov/ 22783261/.

49. Finelli C. Obesity and immunotherapy: The surprisingly positive association. Immunotherapy. 2020;12(8): 541-44.

Accessed 12 December 2020

Available:https://www.futuremedicine.com/ doi/full/10.2217/imt-2019-0143

50. Sánchez-Jiménez $F$, Pérez-Pérez $A$, de la Cruz-Merino L, Sánchez-Margalet V. Obesity and breast cancer: Role of leptin. Front Oncol. 2019;9:596.
Accessed 10 December 2020

Available:https://pubmed.ncbi.nlm.nih.gov/ 31380268/

51. Hayes AJ, Larkin J. BMI and outcomes in melanoma: more evidence for the obesity paradox. Lancet Oncol. 2018;19(3):26970. Accessed 12 December 2020

Available:https://pubmed.ncbi.nlm.nih.gov/ 29449191/

52. Lu Z, Xie J, Wu G, Shen J, Collins R, Chen $\mathrm{W}$, et al. Fasting selectively blocks development of acute lymphoblastic leukemia via leptin-receptor upregulation. Nat. Med. 2017;23:79-90.

Accessed 5 December 2019

Available:https://pubmed.ncbi.nlm.nih.gov/ 27941793/

53. Alissafi T, Hatzioannou A, Legaki Al, Varveri $A$, Verginis $P$. Balancing cancer immunotherapy and immune-related adverse events: the emerging role of regulatory $\mathrm{T}$ cells. J. Autoimmun. 2019;104.

Accessed 16 January 2020

Available:https://pubmed.ncbi.nlm.nih.gov/ 31421963/

54. Tsai HF, Hsu PN, Kung JT. Cancer immunotherapy by targeting immune checkpoints: mechanism of $T$ cell dysfunction in cancer immunity and new therapeutic targets. J. Biomed. Sci. 2017;24:35.

Accessed 18 December 2020

Available:https://jbiomedsci.biomedcentral. com/articles/10.1186/s12929-017-0341-0/.

55. Ansell SM, Lesokhin AM, Borrello I, Halwani A, Scott EC, Gutierrez M, et al. PD-1 Blockade with nivolumab in relapsed or refractory hodgkin's lymphoma. New Engl. J. Med. 2015;372:311-9.

Accessed 10 February 2020

Available:https://pubmed.ncbi.nlm.nih.gov/ 25482239/

56. Wolchok JD, Kluger $H$, Callahan MK, Postow MA, Rizvi NA, Lesokhin AM, et al. Nivolumab plus Ipilimumab in advanced melanoma. Engl. J. Med. 2013;369:12233.

Accessed 5 December 2019.

Available:https://www.nejm.org/doi/full/10.1 056/nejmoa1302369/.

57. Simpson TR, Li F, Montalvo-Ortiz W, Sepulveda MA, Bergerhoff K, Arce F, et al. Fc-dependent depletion of tumor-infiltrating regulatory $t$ cells co-defines the efficacy of 
anti-CTLA-4 therapy against melanoma. J. Exp. Med. 2013;210:1695-710.

Accessed 5 November 2019

Available:https://pubmed.ncbi.nlm.nih.gov/ 23897981

58. Chung KY, Gore I, Fong L, Venook A, Beck SB, Dorazio P, et al. Phase II study of the anti-cytotoxic T-lymphocyteassociated antigen 4 monoclonal antibody, tremelimumab, in patients with refractory metastatic colorectal cancer. J. Clin. Oncol. 2010;28:3485-90.

Accessed 10 November 2019

Available:https://pubmed.ncbi.nlm.nih.gov/ 20498386/

59. Selby MJ, Engelhardt JJ, Quigley $M$, Henning KA, Chen T, Srinivasan M, et al. Anti-CTLA-4 antibodies of IgG2a isotype enhance antitumor activity through reduction of intratumoral regulatory $\mathrm{T}$ cells. Cancer Immunol Res. 2013;1:32-42.

Accessed 19 November 2019.

Available:https://cancerimmunolres.aacrjou rnals.org/content/1/1/32/

60. Pelster MS, Amaria RN. Neoadjuvant immunotherapy for locally advanced melanoma. Curr. Treat. Options Oncol. 2020;21(2):10.

Accessed 12 December 2020

Available:https://pubmed.ncbi.nlm.nih.gov/ 32025932/

61. Byeon S, Cho JH, Jung HA, et al. PD1 inhibitors for non-small cell lung cancer patients with special issues: Real-world evidence. Cancer Med. 2020;9(7):2352-62. Accessed 12 December 2020

Available:https://pubmed.ncbi.nlm.nih.gov/ 32027780/

62. Jensen SM, Maston LD, Gough MJ, Ruby $\mathrm{CE}$, Redmond $\mathrm{WL}$, Crittenden $\mathrm{M}$, et al. Signaling through OX40 enhances antitumor immunity. Semin. Oncol. 2010;37:524-32.

Accessed 27 January 2020

Available:https://www.sciencedirect.com/sc ience/article/abs/pii/S0093775410001 $673 /$.

63. Zappasodi R, Sirard C, Li Y, Budhu S, Abu-Akeel M, Liu C, et al. Rational design of anti-GITR-based combination immunotherapy. Nat Med. 2019;25:75966.

Accessed 13 January 2020.

Available:https://www.nature.com/articles/s 41591-019-0420-8/.

64. Li S, Liu M, Do MH, Chou C, Stamatiades EG, Nixon BG, et al. Cancer immunotherapy via targeted TGF- $\beta$ signalling blockade in Th cells. Nature. 2020;587(7832):121-25.

Accessed 11 December 2020

Available:https://www.nature.com/articles/s 41586-020-2850-3/.

65. Sarkar A, Donkor MK, Li MO. T cell- but not tumor cell-produced TGF- $\beta 1$ promotes the development of spontaneous mammary cancer. Oncotarget. 2011;2(12): 1339-1351.

Accessed 11 December 2020

Available:https://www.ncbi.nlm.nih.gov/pm c/articles/PMC3282091/

66. Donkor MK, Sarkar A, Li MO. TGF- $\beta 1$ produced by activated $\mathrm{CD} 4+\mathrm{T}$ cells antagonizes $\mathrm{T}$ cell surveillance of tumor development. Oncolmmunology. 2012; 1(2):162-171.

Accessed 11 December 2020

Available:https://www.ncbi.nlm.nih.gov/pm c/articles/PMC3376999/

67. Qureshi OS, Zheng Y, Nakamurama K, Attridge K, Manzotti, C, Schmidt, EM, Baker, J, Jeffrey, LE, Futter, CE, Anderson G, Walker, LSK, Sansom DM. Trans endocytosis of CD80 and CD86: A molecular basis for the extrinsic function of CTLA-4. Science. 2011;332(6029):600603.

Accessed 10 December 2020.

Available:https://www.ncbi.nlm.nih.gov/pm c/articles/PMC3198051/

68. Onish Y, Fehervari Z, Yamaguchi T, Sakaguchi S. Foxp3+ natural regulatory $T$ cells preferentially form aggregates on dendritic cells in vitro and actively inhibit their maturation. Proc Natl Acad Sci U S A. 2008;105(29):10113-10118.

Accessed 11 December 2020

Available:https://www.ncbi.nlm.nih.gov/pm c/articles/PMC3376999/

69. Yan Z, Sanjay KG, Ruma B. Regulatory T Cells Interfere with Glutathione Metabolism in Dendritic Cells and T Cells. J Biol Chem. 2010;285(53):41525-41532.

Accessed 10 December 2020.

Available:https://www.ncbi.nlm.nih.gov/pm c/articles/PMC3009879/

70. Liang $\mathrm{B}$, Workman $\mathrm{C}$, Claude Chew JL, Dale BM, Colonna L, Flores M, Li N, Schweighoffer E, Greenberg S, Tybulewicz V, Vignali D, Raphael C. Regulatory T cells inhibit dendritic cells by lymphocyte activation gene-3 engagement of $\mathrm{MHC}$ class II. J Immunol. 2008;180(9):59165926. 
Accessed 11 December 2020

Available:https://www.ncbi.nlm.nih.gov/pm c/articles/PMC39648752/.

71. Rueda CM, Jackson CM, Chougnet CA. Regulatory T-Cell-Mediated Suppression of Conventional T-Cells and Dendritic Cells by Different cAMP Intracellular Pathways. 2016;7:2016.

Accessed 11 December 2020.

Available:https://www.ncbi.nlm.nih.gov/pm c/articles/PMC4889573/.

72. Akkaya B, Oya Y, Akkaya M, Jafar Al Souz $\mathrm{JA}$, Holstein $\mathrm{AH}$, Kamenyeva $\mathrm{O}$, Kabat $\mathrm{J}$, Matsumura R, Dorward DW, Glass D, Shevach EMT regulatory cells mediate specific suppression by depleting peptideMHC class II from dendritic cells. Nat Immunol. 2019;20(2):218-231.

Accessed 12 December 2020.

73. Tadokoro CE, Shakhar G, Shen S, Ding Y, Lino AC, Maraver A, Lafaille JJ, Dustin ML. Regulatory $\mathrm{T}$ cells inhibit stable contacts between CD4+ T cells and dendritic cells in vivo. J Exp Med. 2006;203(3):505-511.

Accessed 12 December 2020.

Available:https://www.ncbi.nlm.nih.gov/pm c/articles/PMC2118249/

74. Mavin E, Nicholson L, Rafez AS, Gao F, Dickinson A, Xiao-nong W. Human Regulatory T Cells Mediate Transcriptional Modulation of Dendritic Cell Function. J Immunol. 2017;198(1):138-146.

Accessed 11 December 2020.

Available:https://www.jimmunol.org/content /198/1/138.short

75. Gondek DC, Lu L.F, Quezada S.A, Sakaguchi S, Noelle, R.J. Cutting edge: Contact-mediated suppression by CD4+CD25+ regulatory cells involves a granzyme B-dependent, perforinindependent mechanism J. Immunol. 2005;174:1783-1786.

Accessed 12 December 2020.

Available:https://www.sciencedirect.com/sc ience/article/pii/S1074761309001976

76. Grossman WJ, Verbsky JW, Tollefsen BL, Kemper C, Atkinson JP, Lev TJ.
Differential expression of granzymes $A$ and $B$ in human cytotoxic lymphocyte subsets and T regulatory cells. Blood. 2004;104(9): 2840-2848.

Accessed 12 December 2020.

Available:www.bloodjournal.org

77. Rubtsov YP, Rasmussen JP, Chi EY, Fontenot J, Castelli L, Ye X, Treuting $P$, Siewe, L, Roers A, Henderson Jr W, Muller W, Rudensky AY. Regulatory $T$ cellderived interleukin-10 limits inflammation et environmental interfaces. Immunity. 2008;28(4):546-558.

Accessed 10 December 2020.

Available:https://www.sciencedirect.com/sc ience/article/pii/S1074761308001131

78. Chaudhry A, Samstein RM, Treuting $P$, Liang $Y$, Pils MC, Heinrich JM, Jack RS, Wunderlich FT, Brüning JC, Müller W, Rudensky AY. Interleukin-10 signaling in regulatory $T$ cells is required for suppression of Th17 cell-mediated inflammation. Immunity. 2011;34(4):546558.

Accessed 11 December 2020.

Available:https://www.ncbi.nlm.nih.gov/pm c/articles/ PMC3088485/

79. Hsu P, Santner-Nanan B, Hu M, Skarratt K, Hiang C, Stormon M, Wong M, Fuller SJ, Nanan R. IL-10 Potentiates Differentiation of Human Induced Regulatory T Cells via STAT3 and Foxo1. J Immunol. 2015;195(8):3665-3674.

Accessed 11 December 2020.

Available:https://www.jimmunol.org/content /195/8/3665

80. Konkel JE, Zhang D, Zanvit P, Chia C, Zangarle-Murray T, Jin W, Wang S, Chen W. Transforming Growth Factor- $\beta$ Signaling in Regulatory $\mathrm{T}$ Cells Controls $\mathrm{T}$ Helper-17 Cells and Tissue-Specific Immune Responses. Immunity. 2017; 46(4):660-674.

Accessed 09 December 2020.

Available:https://www.ncbi.nlm.nih.gov/pm c/articles/ PMC28423340/

(C) 2020 Medeiros et al.; This is an Open Access article distributed under the terms of the Creative Commons Attribution License (http://creativecommons.org/licenses/by/4.0), which permits unrestricted use, distribution, and reproduction in any medium, provided the original work is properly cited.

Peer-review history:

The peer review history for this paper can be accessed here: http://www. sdiarticle4.com/review-history/63638 